\title{
LITERARY APPROACHES TO SLAVERY AND THE INDIES ENLIGHTENMENT:
} VAN HOGENDORP'S KRASPOEKOL

Ann Kumar

\author{
Introduction
}

The Author and His Circle

Willem van Hogendorp spent only ten years (1774-1784) in the Indies, but they were the years when the "Batavian Enlightenment" first put into print its new ideas on welfare, progress, and the cultivation of the arts and sciences. Van Hogendorp's background, education, and 1 iterary connections in the Netherlands, and his central location and high position in the Indies, seem to have destined him for a prominent part in this activity. He was one of an old aristocratic family from the province of North Holland, whose members had been distinguished since the fourteenth century as jurists, members of municipal and national assemblies, and military commanders, not only for the Orangist cause but also in the service of other European powers. Born in 1734, Willem was the son of Diederik van Hogendorp and Catharina Wilhelmina gravin van Hogendorp. 1 Like his father he studied 1 aw at university, though at Leiden instead of Utrecht. He was graduated in April 1754 and in 1759 he became a member of the Collegie van Schepenen (College of Magistrates) at Haarlem. In 1760 he married Jonkvrouw Carolina Wilhelmina van Haren in sensational and scandalous circumstances. Whatever the legacy of these events for $h$ is personal relationship with his wife's family, van Hogendorp was clearly brought with in the sphere of influence of two major literary figures who were the first to treat Indies subjects. 2

In the 1760s van Hogendorp held a number of positions in city government and became a Regent of Rotterdam, his native town. During this period he maintained his family in great luxury, which eventually led him to risk his reduced finances in speculative ventures. In 1774 he faced bankruptcy, from which he was rescued by the patronage of Willem $V$, who arranged for his entry into the VOC at a high level. He was appointed Resident of Rembang in 1774, remaining there until 1777 when he became second (and subsequently first) administrator of the Company's establishment on the island of Onrust (Pulau Kapal) at the western entry to the bay of Batavia. Onrust was a major shipyard for the Company and also the location of a number of warehouses for such products

1. On the van Hogendorp family, see: P. C. Molhuyssen et al., eds., Nieuw Nederlandsche Biographische Woordenhoek [henceforth NNBW] (Leiden: Sijthoff), vols. 2 (1912), 4 (1918), 7 (1927), 8 (1930), and 10 (1937) and A. Winkler Prins, Geillustreerde Encyclopaedie, vol. 8 (Amsterdam: L. Brinkman, 1876). On Willem (1734-84) see also J. P. Cornets de Groot van Kraaijenburg, "Levensschetsen: Dirk van Hogendorp," in Handelingen en geschriften van het Indisch genootschap (1856), p. 33-125.

2. See Appendix, below p. 64. 
as pepper, coffee, copper (from Japan), and tin. Though its climate was considered extremely unhealthy, Onrust was a particularly lucrative posting because of the opportunities it offered to engage in private trade, which was officially prohibited by the Company. 3 It seems that willem, who kept his own ship, used this opportunity to its utmost, and in 1784, having amassed a large fortune and made not a few enemies among the colony's elite, he decided to return home. According to Nieuwenhuys, one of his enemies remarked as Willem embarked on the Harmonia: "If there is a just God in heaven, that man can never reach the Cape." 4 Nor did he: nothing more was ever heard of the ship or its passengers.

As already noted, however, while in the Indies van Hogendorp's activities were not wholly commercial. He was one of the founders and first directors of the Bataviaasch Genootschap van Kunsten en Wetenschappen [Batavian Society for the Arts and Sciences], established in 1778 to promote agriculture and trade, the general welfare of the colony, and the channeling of its production to the benefit of the home country, as well as the arts and sciences. Its earliest publications, the first volumes of the Verhandelingen [VBG], reveal a developing $v$ ision of Dutch Java as a settled colony with an industrious rural population rather than a network of somewhat isolated outposts for the collection of produce. Van Hogendorp contributed to the first VBG (1779) a Korte schets van de bezittingen der Nederlandsche oost-Indische Maatschappij, benevens eene beschrijuing van het koningrijk Jacatra en de stad Batavia [Short sketch of the possessions of the Dutch East-India Company, together with a description of the Kingdom of Jacatra and the city of Batavia], written jointly with J. C. M. Radermacher, the Society's president (VBG I, 1779), and a Beschrijuing van het eiland Timor, voor zover het tot nog toe bekend is [Description of the island of Timor, to the extent that it is known to date].

He also published two self-contained works. The first was Sophronisha, of de gelukkige moeder door de inenting van hare dochters, ter lezing voorgesteld aan de moeders van Batavia [Sophronisba, or the fortunate mother through the vaccination of her daughters, presented to be read by the mothers of Batavia], first published in Batavia in 1779,5 just two years after $h$ is father-in-law, Onno Zwier van Haren, in a Tyric poem, De Inenting ("Vaccination": actually of course variolation at that period), had praised this controversial new practice. It is the story of a married couple called Lysander and Sophronisba who live in "one of the foremost cities of Holland." Lysander is a great advocate of vaccination; Sophronisba, as a mother, is afraid of the risks, and her fears are reinforced by the opposition of an old, conservative doctor. Lysander decides to take the responsibility upon himself and has both their daughters inoculated (a detalled description of the patients' reactions and the manifestation of the vaccine is given). Shortly afterwards a smallpox epidemic breaks

3. For a brief history of Onrust, see D. G. Stibbe et al., eds., Encyclopaedie van Nederlandsch Oost-Indie, 2nd ed., 4 vols. (The Hague: Nijhoff/Leiden: Brill, 1917-21), 3:133-34. According to contemporary Batavian lore, three years in such a post was sufficient to allow a man to return home a millionaire.

4. Rob Nieuwenhuys, oost-Indische Spiegel: wat Nederlandsche shrijuers en dichters over Indonesie hebben geschreven, vanaf de eerste jaren der Compagnie tot op heden (Amsterdam: Querido, 1973), p. 67.

5. The edition used for this article was published in 1921 under the title Mr. W. van Hogendorp, Geneeskundige Propagandageschriften, Javasche Boekhandel en Drukkery (Rijswijk?), and contains both Sophronisba and the Redevoering der inenting tot de ingezetenen van Batavia. 
out in the city, leading to mortality among young and old. Lysander's daughters recover from the mild illness caused by vaccination, while the old doctor loses his wife and son, one of his daughters becomes lame and the other blind. Naturally, Sophronisba tells everyone who will 1 isten that she is a fortunate mother because of her daughters' vaccination. Nieuwenhuys describes Sophronisba as an example of a characteristic eighteenth-century attitude: wisdom (not virtue) is rewarded, a closed mind (not evi1) brings its fitting punishment. 6

Van Hogendorp also funded a prize of 100 gold ducatoons to be awarded by the Bataviaasch Genootschap for the best essay on the subject of vaccination (similar competitions--called prijsuraagen--were to be run in learned journals throughout the colonial period). In the second volume of the VBG it was reported that the death of a child who had been vaccinated had caused a general panic and rejection of the practice, which led van Hogendorp to publish a Redevoering der inenting tot de ingezetenen van Batavia [Address concerning vaccination to the inhabitants of Batavia]. 7 Van Hogendorp was convinced of the necessity of pushing forward with the vaccination program to combat the smallpox then prevalent all over Java, and seems himself to have vaccinated not only Europeans but a) so Chinese and Javanese, though he was not a medical man. 8

The second of van Hogendorp's publications was Kraspoekol, translated here, published first in Batavia in 1779 by the government printer Lodewyk Dominicus (on the Tijgersgracht) and then in Rotterdam by the printer R. Arrenberg, in 1780 , along with Sophronisba.

\section{Kraspoekol and Slavery}

Kraspoekol was not the first Dutch literary work to treat slavery as a moral problem. Montesquieu had initially placed the problem of slavery on the agenda of the Enlightenment, though it was somewhat later, during the 1760 s and 1770s, that consclousness of its evils began to spread among educated and progressive Europeans. In the Netherlands, the literature of this period was considerably influenced by the new formulations menschenliefde (love of humanity) and menschenuriend (philanthrope), and by the idea that all humanity (menschdom) were one family, children of one Father. These ideas led writers like Betje Wolf and Simon Rivier to abominate slavery; 9 and are echoed in the words-"Humane Wedanol" (Menschl ievende Wedano!) which Kraspoekol's narrator addresses to its hero.10 The inhumanity (onmenselijkheid) of the trade in slaves had been exposed in at least one earlier literary work, 11 though this is not Kraspoekol's subject. And other subjects which raised questions concerning the

6. Nieuwenhuys, Spiegel, p. 68.

7. See note 5 above. The written text has the form of a formal address, but it is not clear to me if and when it was delivered.

8. Van Kraaijenburg, "Dirk van Hogendorp," pp. 35-36.

9. See G. Kalff, Geschiedenis der Nederlandsche Letterkunde, vol. 6 (Groningen: Wolters, 1910): 28-29.

10. See below p. 61.

11. In Gerbrand Adriaanszoon Bredero's Moortje, written in the second decade of the seventeenth century: see Reinder P. Meijer, Literature of the Low Countries: A Short History of Dutch Literature in the Netherlands and Belgium (Assen: van Gorkum and Prakke, 1971), P. 124. 
morality of Dutch actions in the Indies had been treated by van Hogendorp's father-in-law, Onno Zwier van Haren, and his brother Willem van Haren.12

But it would be wrong to look for Kraspoekol's antecedents only, or even mainly, in Dutch 1 iterature, as the banner quotation from Alzire with which it opens sufficiently alerts us. Its points of resemblance with Voltaire's Alzire are immediately apparent. Like Kraspoekol. Alzire deals with a situation resulting from the conquest of a non-Christian people by Christian colonizers: in Alzire, the Spanish conquest of Peru. In both works the dramatic tension hinges upon the difference between ascriptive status (whether social or religious) and innate qualities--the unchristian Christian, the noble savage. Both van Hogendorp and Voltaire have made their savages noble in both senses of the word; Alzire is an Indian princess, her beloved Zamore also of the ruling class; Campaka, though enslaved, is actually the daughter of a Raja. This insistence on maintaining the link between nobility and Nobility was by no means universal: in Tristram Shandy (published thirteen years before Kraspoekol), for instance, the poor negro girl has learned kindness though she has been shown none, implying the more radical possibility of the spiritual development of an individual of undistinguished background raised in the least promising environment. 13

There are significant differences, however, between Kraspoekol and Alzire, made more striking by their very similarities, and they are not just in the depth and subtiety of Voltaire's critique of the perversion of Christian ideals, or in his literary primacy. Alzire is in many ways the less conservative of the two texts, notably in its radical denouement of the conflict between rulers and ruled: Alzire and Zamore not only survive the cruel persecution of a Spanish governor but are installed to rule over their people.14 No such bouleversement is contemplated for Kraspoekol. In any comparison with Alzire, however, one should set the conservatism of van Hogendorp's resolution of the conflict against the risks he embraced in his use of Batavia as the setting of his "moral story." It is one thing to portray the established order as unjust and immoral (and therefore susceptible of overthrow) in a distant exotic locale-someone else's colony--as in Voltaire's case; quite another even to adumbrate such suspicions for one's own colony as van Hogendorp did--and knew he did, as we can read from his nervous disclaimer that "It is not my intention... to give anyone the idea that the slaves of Batavia are in general i11-treated. -. I am convinced that the slaves are better treated in this distinguished place, than in any other possession of Europeans."15

Nieuwenhuys sees Willem van Hogendorp's text as bearing the stamp of Rousseau in that he treats slavery not as a social but as a moral problem. 16 Certainly,

12. See Appendix, below pp. 64-65.

13. Laurence Sterne, The Life and Opinions of Tristram Shandy, Gentleman, ed. James Aiken Work, vo1. 9 (New York: The Odyssey Press, 1940), ch. 6, pp. 606ff.: this is the chapter which contains the famous affirmation that the negro has a soul.

14. For an edition of Voltaire's Alzire, see oeuures completes de Voltaire avec des remarques et des notes historiques, scientifiques et litteraires. Theatre Tome II, deuxieme edition (Paris: Baudou in frères, 1828), pp. 466-537. Verdi's Alzira is also based on this work.

15. Kraspoekol, Foreword, p. 54 below.

16. Nieuwenhuys, Spiegel, p. 69. 
he appears to take the institutional and economic aspects of slavery as unquestionably part of the given order of things: vide for example the brief appearance in a footnote of the Company's work-places as a recommended avenue through which slave owners can earn interest on their investment. 17 But two points might be made here: first, it is always difficult to interpret a text's silences. Should van Hogendorp's silence on the effect of the enormous economic interests of the VOC elite in maintaining the slave tradel8 be seen as an indication of a naive lack of understanding of the root causes of the abuses of slavery, or of his prudent avoidance of a sensitive subject?19 Second, even within a viewpoint 1 imited to "abuses" and "moral problems" one has, after all, a choice of which abuses to highlight. It will be noted that the abuses which van Hogendorp describes are not committed by a Dutchman at al1, but by a connection of a Portuguese mestizo family "of the third or fourth rank," a woman whose social reality is obscured by the use of the soubriquet "Kraspoekol." The choice of such a locale--domestic, nonelite, largely feminine--for a description of the mistreatment of slaves turns the spotiight away from other locales: Roti, for example, where entire domains were destroyed and their population enslaved for the profit of the Company and its officers, 20 opening the question of the abuses involved in the "illegal" enslavement of free people by traders. Given that its author has chosen the domestic locale, however, can his picture of the lot of the house slave be taken as representative? Since more than half of the population of Batavia at this time were slaves, and perhaps two-thirds of them were owned by Europeans, this is an interesting question. 21

Travelers to the Indies generally confirm van Hogendorp's assertion that slaves were as a rule well treated except for abuses, some of them extremely barbarous, inflicted by female owners. 22 Many nineteenth century reports state that Europeans treated their slaves considerably better than non-European

17. See below p. 58 .

18. On the enormous profits to be made in the slave trade, its brutal and violent character, and slave holding as a major form of capital investment by Company employees, see, for example, Heather Sutherland, "Slavery and the Slave Trade in South Sulawesi, 1660s-1800s," in Slavery. Bondage and Dependency in Southeast Asia, ed. Anthony Reid (St. Lucia: University of Queensiand Press, 1983), pp. 270-71.

19. That van Hagendorp was not entirely unaware of slavery as an institutional problem is suggested by his sponsorship, jointly with J. C. M. Radermacher, of a prize for the best essay submitted to the Bataviaasch Genootschap on the replacement of house slaves by free native Christian servants: see G. J. Schutte, De Nederlandse Patriotten en de kolonien: een onderzoek naar hun denkbeelden en optreden 1771-1800, Historische Studien: Rijksuniversiteit te Utrecht, Instituut voor Geschieden is (Groningen: Tjeenk Willink, 1974), p. 146.

20. See J. Fox, "For Good and Sufficient Reasons: An Examination of Early Dutch East India Company Ordinances on Slaves and Slavery," in Slavery. Bondage and Dependency in Southeast Asia, p. 250.

21. See S. Abeyasekere, "STaves in Batavia: Insights from a Slave Register," in ibid., Pp. 288-89 and $296 \mathrm{ff}$.

22. This general picture, differing only in details over the eighteenth century, is outlined in Jean Gelman Taylor. The Social World of Batavia: European and Eurasian in Dutch Asia (Madison: University of Wisconsin Press, 1983), pp. 4142 and 213 , n. 11. 
(mainly Chinese and Arab) owners.23 Such accounts and reports are written by male Europeans. We have, so far, no Asian account of master-slave relationships in European households. However, when women--Dutch women--beg in to write about domestic power relationships at a later stage of the colonial period, a major theme is sexual exploitation, most commonly of the nyai (Indonesian de facto wife) by the Dutch head of household,24 and it is hard to bel leve that this exploitation did not occur earlier within the still less free contract of slave and owner. Even with the use of more detailed records such as judicial cases, it seems unlikely that we will be able accurately to quantify the incidence of abuses among the different races and sexes. It may be more profitable to look instead at what Kraspoekol tells us about "normal," accepted conditions within Batavian slave-holding households of this period.

The reader will certainly note many of the "given" features of slave life-sexual pairing of male and female slaves; usage of opium; the general assumption that male slaves would supplement insufficient pocket money by nocturnal robbery--and further comment here is perhaps otiose. Even more striking than the text's evidence on the accepted features of the slave-household and slave-city landscape, however, is its implicit indication of van Hogendorp's views on discipline, violence, and punishment. He is horrified at Kraspoekol's beating of her slaves because it is unjust, though he accepts, as we see, corporal chastisement, at least of male slaves, as necessary in some cases to maintain discipline. 25 To the modern reader, however, it is his acceptance without comment of the way in which the murderous, but nevertheless gravely wronged, slave must die which sits most oddly with his espousement of a humanitarian viewpoint.

It is true that, at the time van Hogendorp was in Batavia, the death sentence could be carried out by many different methods at the discretion of the executioner: apart from breaking on the wheel, other possible choices were hanging, beheading, strangling, krissing (only for natives), and quartering. What the Encyclopaedie van Nederlandsch Oost-Indie describes as "frightful spectacles"26.dismemberment of the corpse in order to cast the pieces to birds of prey, impaling of heads--sometimes took place after death. It is also true that the 1 aw required that the death penalty be applied "in the most rigorous fashion" 27 to those who, while in a "state of amok" had been in possession of any weapon. The breaking on the wheel with which Kraspoekol ends was presumably considered

23. See Abeyasekere," Slaves in Batavia," p. 305.

24. See J. S. Taylor, "The World of Women," Kabar Seberang/Sulating Maphilindo 2 [June 1977]: 26-41 for an account of the dominant themes in the writings of Dutch women in the Indies in the high colonial period. It is also interesting to note that the position of the nyai in liaisons with Chinese men is seen as a very unequal one in prewar peranakan Chinese 7 iterature, thus tending to develop a picture of the sexual exploitation of native women by the men of the economically dominant communities: see Margaret Bocquet-Siek, "Some Notes on the Nyai Theme in Pre-War Peranakan Chinese Literature," paper presented at the 5th conference of the Asian Studies Association of Australia, Adelaide, May 13-19, 1984 .

25. See below Pp. 57-58.

26. Vol. 4, p. 136.

27. Ibid. 
"rigorous."28 But it is not true that this harsh punitive code was universally considered tolerable until reforming winds swept through the colony at a much later era which began with Daendels and Raffles.29 As early as 1780, van Hogel urp's colleague on the Bataviaasch Genootschap, J. C. M. Radermacher, wrote an interesting article in the $V B G^{30}$ arguing for the abolition, or at least the drastic curtailment, of both the death penalty and torture (another feature of the penal code to be attacked by Daendels and Raffles). He claims that the death penalty involves economic disadvantages to society and quotes the work of the Marquis Beccaria, the Italian reformer who was the principal mover of the anti-capital-punishment movement that began in the 1770s. He also points to the English move away from torture and the reforms of Catherine the Great as positive examples. So it is perhaps after all of some significance that the narrator of Kraspoekol, generally rather 1 iberal in his comments on the moral correctness or otherwise of the actions he describes, passes over this scene in silence.

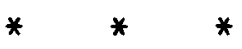

A revision of Willem van Hogendorp's Kraspoekol--what the Javanese textual tradition would call a putra, an offspring-was produced, neatly enough, by his eldest son Dirk. Dirk's Indies career was both more spectacular on the personal level and more productive for the theory of colonial administration in the age of reform than his father's.

When willem left for the Indies, his sons Dirk (b. 1761) and Gijsbert Karel (b. 1762)31 were taken under the protection of Princess Wilhelmina, wife of Willem V. Niece of the king of Prussia, she had the two boys educated at the Berl in military cadet-school for sons of the nobility. Thereafter the brothers' paths diverged. Gijsbert Karel became one of the Netherlands' best-known statesmen and economists, and Dirk embarked upon a spectacular career whose Indies' component will be known to most readers of these pages. In 1784 he went out with the squadron of van Braam (which rescued Malacca from Raja Haji's

28. For further information on this form of punishment the interested reader is referred to Folke Strom, On the Sacral Origin of the Germanic Death Penalties (Stockholm: Wahlstrom and Widstrand, 1942), pp. 214-24. Folke classifies punishments as male, female, or gender-neutral, and along a continuum between strongly ritualistic (stoning, burning) and predominantiy pragmatic (hanging). In the Middle Ages breaking on the wheel was predominantly a male punishment, though it was earlier used for witches. It is a "ritual" punishment (Folke speculates that the wheel is a solar symbol) and avoids the taboo on lifetaking by allowing the victim to die slowly of his injuries. Folke's claim that this punishment originates in pre-Christian penal law relating to slaves is rather striking in the present context.

29. On the reforms of Daendels and Raffles see Encyclopaedie van Ned. OostIndie 4:131-32. The work of reform that they began was not fully implemented until the legal reforms of the late $1860 \mathrm{~s}$ and early 1870 s introduced the Code Penal for Europeans and a criminal law code for natives based on the same model, though differing where the government considered religion, custom, or other local peculiarities made this necessary.

30. Vol. 2, pp. 319-26, "Over de doodstraffe en het pynigen."

31. The date of Gijsbert Karel van Hogendorp's birth is erroneousiy given as 1771 in NNBW, vol. 2. 
Buginese), 32 arriving in Batavia in time to meet his father who was on the point of leaving for home on the ill-fated Harmonia.

Dirk now entered the service of the VOC, and after a few years in Bengal was appointed to his father's old position on Onrust. He subsequentiy became Resident of Japara, and finally, in 1794, was appointed to the position of Opperkoopman en gezaghebber van Java's oosthoek (senior merchant and commandant of Java's northeast coast).

In 1795, after many years of pro- and anti-Orangist conflict, the forces of change in Europe became too powerful for the Dutch elite to control, and the Batavian Republic was established under the protection of Revolutionary France. Willem $V$ fled to England, and ceded authority over the Dutch colonies to the British. This left the colonial authorities to decide whether they should take their orders from the Republic or from the exiled Stadhouder. Generally speaking, the most powerful members of the VOC's clique-ridden hierarchy (the AltingSiberg-Nederburgh group) resisted the revolutionary ride, but Dirk van Hogendorp, despite his family history and his own debt to the house of Orange, chose for the Republic--for its political alignment with France, and for its egalitarian ideas. 33

His criticisms of VOC practice, a rich field of special interests and duplicity, from this standpoint, brought a characteristically draconian response. He was first dismissed from his post, then brought to Batavia under military escort. After months of detention without trial he managed to make his escape on a Danish ship. On the voyage home he wrote his Brief aan alle urijheid en vaderland lievende Bataven [Letter to all freedom and fatherland loving Batavians] and shortly after his arrival in the Netherlands published his Berigt van den tegenwoordigen toestand der Bataafsche Bezittingen in oost-Indien en den handel op dezelve [News of the present situation of the Batavian possessions in East India and their trade] (Delft, 1799). He 1ater wrote: Stukken, over hetzelfde onderwerp [Pieces on the same subject] (The Hague, 1801); Ontwerp om de oost-Indische Compagnie te herstellen tot een handeldrijvend ligchaam [Design to reestablish the East India Company as a trading body] (The Hague, 1801); Antwoord op het onderzoek der gronden van het stelsel van $D$. van Hogendorp [Answer to the inquiry into the bases of the system of $D$. van Hogendorp] (The Hague, 1802); Nadere witlegging en ontwikkeling van het stelsel van Dirk van Hogendorp, in antwoord op het werk van S. C. Nederburgh, getiteld, Verhandeling over de uragen, enz. [Further en largement and development of the system of Dirk van Hogendorp, in answer to the work of S. C. Nederburgh, entitied, Treatise concerning the questions, etc.] (1802), and Aanmerkingen op het adres van participanten der Nederl. 0. I. Compagnie aan het Staatsbewind der Bataafsche Republiek [Remarks on the address of shareholders of the Dutch E. Indian Co. to the Government of the Batavian Repub 1 ic] (The Hague, 1802). 34

It was to take eight and a half years before he was cleared of the charges brought against him of exploiting his position of authority in Java (he also published, in his defense, a Verzameling van Stukken, raakende de zaak van Dirk

32. On the van Braam expedition and its context, see D. G. E. Hall, A History of South-East Asia (London: Macmillan, 1961), p. 293.

33. See van Kraaijenburg, "Dirk van Hogendorp," pp. $38 \mathrm{ff}$. and Schutte, Nederlandse Patriotten, p. 172.

34. Van Kraaijenburg, "Dirk van Hogendorp," PP. 119-20 and Schutte, Nederlandse Patriotten, Pp. 178-89. 
van Hogendorp [Collection of pieces relating to the case of Dirk van Hogendorp]), 35 but he was, nevertheless, appointed in the meantime to the committee set up to decide on the shape of Indies government after the abolition of the VOC. The struggle for supremacy between van Hogendorp and his old enemy Nederburgh are part of the textbook history of Indonesia, and we know that van Hogendorp's "system" as drawn up in the publications listed above had only a 1 imited influence on the nineteenth century Indies. 36 Its basic points: the separation of government from commercial interests; personal ownership of 1 and; freedom of person, with the abolition of compulsory labor; and freedom of trade, represent a liberal program deriving from Adam Smith never seriously attempted either in the colony or in its successor state.

Van Hogendorp himself was not appointed, as he had hoped, to the GovernorGeneralship of the Indies. His subsequent career was shaped by the Napoleonic wars: he was appointed ambassador to St. Petersburg, then minister of war and commander of the army by appointment of Lou is Bonaparte, King of the Netherlands, and ultimately aide-de-camp of Napoleon with the title of le Comte de l'empire (superseding the Republican "D. van Hogendorp" of his publications above). He was made Napoleonic governor of East Pomerania and Breslau, and subsequentiy commandant of Königsberg, Vilna, and Hamburg (where his exercise of power had once again to be defended against charges of severity and oppression); and finally, after the defeat of Napoleon, left Europe to plant coffee in Brazil, where he died in 1822.

On the issue of slavery Dirk took a far more radical position than his father. Already in 1796, the year after the proclamation of the Batavian Republic, he had written in Surabaya a Proeve over den slavenhandel en de slavernif in Nederlandsch Indie [Essay on the slave trade and slavery in the Netherlands Indies], published in his Stukken rakende den tegenwoordingen toestand der Bataafsche bezittingen in oost-Indie... , in which he proposed that emancipation should begin with the children: this in answer to the objection that it is necessary to learn how to live as a free man, if the events which followed the French emancipation are to be avoided,37 On his return to the

35. The accusations brought against Dirk van Hogendorp, of enriching himself by extortion and exaction from the Chinese and Javanese populations under his control, and his defense against these charges, have recently been reexamined by C. Fasseur ("Schandaal in Soerabaja: de schorsing van Dirk van Hogendorp als gezaghebber van Java's Oosthoek in 1798," in S. Groeneveld, M. E. H. N. Mout, and I. Schiffer, Bestuurders en geleerden: opstellen over onderwerpen wit de Nederlandsche geschiedenis van de zestiende, zeventiende en achttiende eeuw; aangeboden aan Prof. Dr. J. J. Woltjer bij zijn afscheid als hoogleraar aan de Rijksuniversiteit te Leiden [Amsterdam, 1985]). Fasseur concludes that the real cause of Dirk's fall was his political isolation in the Indies and his rash personal ambition.

36. The best English-language account of Dirk van Hogendorp's system and the subsequent influence of his ideas on government policy for the Indies is still J. S. Furnival1, Netherlands India: A Study of Plural Economy (Cambridge: Cambridge University Press, 1939; reprinted 1967), pp. 56-63, 65, 69, 72, 81, 84,85 , and 86 .

37. On Dirk van Hogendorp's report on slavery in the Indies and his emancipation proposals, see van Kraaijenburg, "Dirk van Hogendorp," Pp. 120-22; Abeyasekere, "Slaves in Batavia," P. 292; and Schutte, Nederlandse Patriotten, PP. 149 and 172. 
Netherlands, he proposed progressive emancipation over a period of twenty years. He had personal experience of slave owning in the Indies, as is apparent from a letter he wrote from Japara on May 14, 1792 to his brother Gijsbert Karel. He asks him to purchase all the instruments "used in a good orchestra," wind, percussion, and strings (at least ten to twelve violins), and a good clavichord or forte piano; as well as the latest Italian and German music. All this was for his slave musicians, of whom he had al ready trained sixteen. He writes "Do not think, dear friend, that this is a useless and ruinous expenditure on luxury. Slaves which cost me 70-80 rijksdaalders will be worth 400-500 each when I have taught them to play; and when I return to Europe, I can realize this price."138 And on his return to the Netherlands, he rewrote Kraspoekol.

The changes that Dirk made to his father's text in rewriting it for the stage are very striking. First, he added a preface, stating that his aim was to make slavery, and still more the slave trade, as hateful and horrible as he could in order to have the slave trade in the Dutch colonies outlawed as speedily as possible, and the institution of slavery itself abolished thereafter. He went on to make significant additions to his father's text: a speech by Wedano, for instance, in which he exclaims "Unnatural slavery, abominable slave-trade, when will you be banned from the earth?" There is a whole new scene which moves the moral opprobrium of the piece far beyond the domestic and feminine locale of the original referred to above: this portrays the visit of a party of important men, of whom the most memorable is a member of the Governor-General's council called Champignon, an arrogant upstart who has risen from the position of ship's boy via a career of deceit and dishonesty to become a millionaire. "Conscience?" he says to Wedano, "I have to laugh if I hear people talk of conscience in the Indies," cynically remarking that, after all, Wedano too had come out to make a buck.

The relationship between Willem van Hogendorp's Kraspoekol and Alzire calls to mind Harold Bloom's Nietzschean-Freudian theory of intertextuality as the struggle of the aspirant poet with a single great precursor. 39 But if Voltaire is well cast as the dominant progenitor, it is hard to see that Willem van Hogendorp rises to the sublime in his struggle with him; in the inevitable comparison between the two texts Kraspoekol seems only a watered-down imitation in both 1 iterary form and ideology. Yet, as suggested above, one may see an element of daring in setting the story within the Batavian society in which van Hogendorp's readership 1 ived, with all the questions that this inevitably opened concerning their own behavior and values. His son Dirk, of course, deliberately pushed his father's text still further in the direction of social criticism. His intention in doing so was dramatically verified by the play's reception, when "the East India Gentry, not thinking it proper to exhibit the most illustrious actions of themselves and their noble ancestors upon a stage . . . went to the play provided with little half-penny whistles and trumpets . . "40 and used

38. See E. du Perron-de Roos, "Correspondentie van Dirk van Hogendorp met zijn broeder Gijsbert Karel," BKI 102 (1943): 166.

39. See Harold Bloom, A Map of Misreading (New York: Oxford University Press, 1975); also his Poetry and Repression: Revisionism from Blake to Stevens (Now Haven: Yale University Press, 1976); and The Anxiety of Influence: A Theory of Poetry (New York: Oxford University Press, 1973).

40. Nieuwenhuys, Spiegel, p. 72, quoting an English observer by the name of Carleton. 
them so loudly and persistently that the play's only performance, in The Hague, on March 20, 1801, had to be abandoned.

\section{The Coming of Reform}

In his attack on slavery as an institution Dirk van Hogendorp was well in advance of Dutch public opinion. The French had outlawed slavery in their colonies as eariy as 1794, though it was reinstituted in 1803.41 When the constitution of the Batavian Republic was drawn up under the influence of French revolutionary ideology, there was no mention of any reform in slave trading or slave holding. This did not go entirely uncontested: certain of the more liberal "Patriots," the radicals who had gained ascendancy in 1795 with the proclamation of the Republic, protested that slavery was incompatible with the Rights of Man, which led to some debate and reconsideration in the National Convention. Forced to choose between ideals and material gains, however, the majority chose for the latter. It was feared that anti-slavery measures would have grave economic and political consequences in the West Ind ies (where slavery had a much more central importance than in the East Indies, just as it was, on the other side of the debate, the plight of the African slave that largely inspired European anti-slavery movements); and that the profits from the slave trade would be lost to other powers.42 Even among those radical enough to follow the French example, then, there were few who advocated moving against slavery.

The Netherlands followed the rest of Europe in abolishing the slave trade in 1814: this was one of the British conditions for the return of the Dutch colonies after the Napoleonic wars. Thereafter, there was 1 ittle pressure for emancipation: neither the churches nor a strong liberal movement gave significant support, as they did in England. The original Revolutionary impetus was lost, and the anti-slavery movement remained a small elite group: the principal Dutch anti-slavery society had a maximum membership of 670 in the 1850s. Emancipation finally came in 1863 (compared with England 1833, and France 1848).43 Ironically, compensation for the West Indian slave owners was financed from the surplus extracted from Java. The colonial government's success in the larger endeavor of reducing a much greater part of the population to something like serfdom under the Cultivation system made the emancipation of the smaller populations of slaves seem less of an impracticable luxury than it had generally been considered when Dirk van Hogendorp advocated it sixty years earlier.

41. David Brion Davis, The Problem of Slavery in Western Culture (Ithaca: Cornell University Press, 1966), pp. 29 and 31.

42. On the Patriots and slavery, see Schutte, Nederlandse Patriotten, pp. 146-49, and P. C. Emmer, "Anti-slavery and the Dutch: Abol ition without Reform," in Anti-slavery, Religion and Reform: Essays in Memory of Roger Anstey, ed. Christine Bolt and Seymour Drescher (Folkestone, England: Dawson, 1980), pp. 84 and 91 .

43. Emmer, "Anti-slavery," Pp. 87-88 and 91-94. 


\author{
KRASPOEKOL \\ OR \\ The sad consequences \\ of an excessive severity towards slaves \\ A Moral Story \\ by \\ Mr. W. van Hogendorpl
}

Esclave infortune!--si ma main, qui ne peut essuyer tes larmes, en fait verser de regret et de repentir à des tyrans, je n'ai plus rien à demander aux Indes; j'y a fait fortune.

Voyage à l'Isle de France \&c. par un Officier du Roi. Tome II. pag. 238.

Foreword

It is not my intention, with this moral story, to give anyone the idea that the slaves of Batavia are in general ill-treated. Such a proposition would run counter to the truth, and to what was written in the description of this city in the first volume of the Monographs of her Society.*

I repeat consequently, that I am convinced that the slaves are better treated in this distinguished place, than in any other possession of Europeans.

But it cannot be denied that there are, here and there, among members of the third and fourth ranks, some who are too severe towards their slaves, and it is for these few, that I have composed this littie piece.

It should not be an occasion for surprise that I have carefully and designedly avoided all pretensions of style, and the ornamentation of astonishing occurrences or complicated developments with which this story might have been enriched, and merely tried to represent the danger of a too cruel treatment in the clearest, simplest, and most natural way. It is not my aim to fill the idle time of a number of readers for a short hour; but to root out, if this be possible, the remnants of an evil from which so many calamities may proceed.

* p. 64: The reference is to the first volume of the Verhandelingen of the Bataviaasch Genootschap der Konsten en Weetenschappen, as it was initialiy called, which contained the "Korte Schets van der bezittingen der Nederlandsche Oostindische Maatschappye" of J. C. M. Radermacher and W. van Hogendorp.

1. Van Hogendorp's syntax and punctuation often make a clause out of what would be a new sentence in modern Dutch, and give an effect, where his characters themselves are given voice, that some would consider artificial; but out of respect for the original, and an unwillingness to impose the standards of another time, I have refrained from reforming it into a more modern idiom. Footnotes marked with an asterisk are the author's.--Trans. 


\section{KRASPOEKOL}

Nous seuTs, en ces $C l$ imats nous sommes les barbares! Alvares dan Alzire, Acte 1 Scene 1

"Oh," Campakka said once to one of the other slave women, "Why has our Master put us under the supervision of his sister-in-law, who seeks to find her pleasure and greatness in the severity of her domestic rule, and the blows that she metes out? Until now I have escaped, but who can be certain, even for a moment? An accident is treated with just as much severity as a deliberate misdeed!"

An old mandor-esse, who wielded the cambok2 under Miss Kraspoekol, heard this complaint through a crack in the door, and ran off immediately to tell her mistress.

It was considered inadvisable to gratify the lust for chastisement at that moment; but rather to wait until Campakka, in one way or another, had overstepped her 1 imits.

Campakka, who was in fact a slave because she had recently been taken as a prize in her own country by the raid of a neighboring enemy; but who, being of royal blood, had more elevated sentiments than the common crowd, took care to do nothing in her misfortune which would earn blows from a reasonable person. It was from pride, and not for the preservation of her beautiful 1 imbs, that she sought to keep her body from the cambok of the mandor-esse.

Thus a long time passed before Miss Kraspoekol could revenge herself; but a plate, that could not withstand the weight of a glass of water because it was cracked, and that partiy fell out of Campakka's hand in pieces, produced the looked-for moment.

Campakka turned pale from fright, and with an unsteady hand held onto the pieces that had not fallen onto the ground; as if to show her innocence thereby. Miss Kraspoekol, on the other hand, acquired a blush of pleasure on her countenance; and at the sound of the fallen pieces the mandor-esse had already rushed forward, fearful that Kraspoekol should have let this good opportunity slip by.

The unlucky slave was consigned to a thrashing, to be arbitrated by the mandor-esse, in the back garden where punishments were usually carried out, so that the Master of the house, if he were not out, should hear the moaning less.

We know how this administration of justice proceeds: two strongly muscled male slaves receive the cambok from the hand of the mandor-esse and, one after the other, beat the buttocks of the slave until the old woman is merciful enough to pronounce the word suda[h]. This has the same force as the descent of the rod in the hands of a Bailiff in the Fatherland, when the executioner flogs someone.

The mandor-esse went forthwith to the assigned place; Campakka followed with downcast eyes, more shamed than afraid. "O my Father!" she said to herself, "You, Chief of a region, and blood-relative of our RAJA! How bitter you would be, if you knew the fate of your daughter!"

2. Cambok. A rhinoceros or hippopotamus hide whip originally used by a wagon driver to lash his oxen. The word (also sambok) is from the Cape Dutch vocabulary, but was evidentiy considered readily applicable to another colonial situation.--Trans. 
Once there, she was tied fast to a ladder, and raised up by her hands, without letting fall a word, or showing any sign of abasement to the one who led her; and she would have received her punishment at once if the back gate of the garden had not unexpectediy opened.

It was none other than Wedano, the brother-in-law of Kraspoekol, who had taken her into his house after the death of his wife.

Wedano had a good disposition, considerable powers of judgment, and a love of humanity. Born in the Indies of a European father and a native-Portuguese mother, who had left him some money, he conducted a profitable business. His warehouses were in the city, and he usually spent the morning there; and during the time of his absence Miss Kraspoekol usually had her punishments carried out.

Wedano, seeing the young Campakka stretched out on a ladder, was moved by pity. He read in her eyes her innocence, and her courage; but above all her trust in his fairness. He also immediately gave the order for her bonds to be loosed, so that he could carefully investigate the reason for her punishment. The mandor-esse ground her teeth with chagrin, and underwent the shame of a tiger that has muffed its spring.

Miss Kraspoek01, who had seen her brother arriving from a distance, understood quite well that if Campakka had not received her punishment before $h$ is arrival, it would not be carried out; thus she existed between hope and fear. But when first Wedano, then Campakka, and after her the mandor-esse came up, she saw, that the thing had not been done, and was furious with malice.

"What? my brother! You have given me the supervision of your house; and if I have a slave chastised, you remit my orders, and expose me to the ridicule of all the others, and of her also!"

"If she is guilty, my sister, she shall receive her punishment, but I want to know first, what she has done."

"What she has done? She has broken one of those plates that cost you a rupiah apiece, and that you like so much."

"And did she deliberately throw this plate on the ground?"

"That I don't know: but it is in pieces, and that is enough."

"That you don't know? Then I am obliged to ask her herself. Your answer is not sincere. Were you not present?"

"I asked for a glass of water; she brought it to me, and dashed glass and plate to the ground: the pieces are still lying there."

"I dare wager, that it happened by accident?"

"Accident or not, she has deserved punishment. I know no accidents with slaves. Bad is bad, and a broken plate is worth nothing any more."

Wedano had meanwhile picked up some of the pieces, and saw on the inside of the porcelain that there was an old crack, which he showed his sister.

"This plate," he resumed, "was cracked in half, and the weight of the glass has made one half fall off, while the other remalned in Campakka's hands. Should you punish a slave, with the utmost severity, for such a mishap? I cannot allow that in my house. If you want to have good slaves, you must overlook mishaps like this."

"Be that as it may," she answered, "my orders must be carried out, or I trouble myself no more with the management of the house: such accidents wouldn't 
happen to me, and I may suffer, so that people. . . " (here she threw herself, still speaking, with so much passion into a chair that the back cracked, and she tumbled over) "Oh, my brother, help me! it's an accident: do help me up!"

"I thought," answered Wedano, reaching his hand out to her, "that there were no accidents of this sort. You are so lucky to be free! this slave breaks a plate worth one rupiah through no fault of hers, and you want to give her a thrashing; but you! you break, in your anger and by your fault, a chair worth five Spanish dollars! May I just know, what is going on in your mind at present?"

Such apposite words had no effect on the vengeful Kraspoekol. She continued to demand the carrying out of the young Campakka's punishment; but Wedano continued to refuse; and after some high words, it was settled that Kraspoekol should not concern herself any more with the household matters, but go to 1 ive with the mandor-esse and her slaves in a distant wing of the house.

Campakka, who had had courage enough to shed no single tear when sentenced by Kraspoekol and taken to the garden by the mandor-esse, wept as she embraced the feet of her benefactor. So strongly does a good deed affect a noble heart; where on the contrary it remains closed and frozen under an unreasonable treatment! She told Wedano what happened dally in his garden when he went to his warehouses; how most of the slave women were punished for trifles, which Kraspoekol and the mandor-esse went out of their way to find, although she had escaped unt1l now; how fortunate all the slaves would consider themselves were they to be directed by him alone; what respect and affection they bore for their master, and how, on the other hand, they were embittered against his sister and the mandor-esse.

Has Nature given to the Nobility of all peoples--to their language, their bearing, their form--something nobler than to the common man? Or was it the youth and beauty of Campakka, or perhaps, all of this, which gave a bewitching power to her words, so that Wedano fancied that he heard something more than a slave speaking?

She must at any rate report to him whose child she was, and how she became a slave; and when he heard who she was and by what unlucky fate she had lost her freedom, he gave the same back to her, and had her letter of manumission drawn up that same day.

Campakka feared that now that she was free she must leave Wedano's house; but he reassured her, and promised to give her the supervision of the household before long, in the meantime commanding the oldest slave woman to keep an eye on everything, and to be responsible for the daily business.

He assembled the other slaves and told them of the change he had made in his house:

"Whenever I hear, or see," he said, "that you have not willfully spoiled or broken something, then I will, at least for the first time, do no more than rebuke you; but whoever lies, steals, gambles, leaves the house at night or commits any other serious offense will be severely punished, and sold on the morrow; for I propose to make it the foundation of my management that no slave whom I have had to have thrashed shall remain in my house."*

* I realize that no one would find it expedient to put off slaves daily, at a 
All were content with these reasonable terms, and in token of their satisfaction fell at the feet of their master.

Kraspoekol was able, for a time, to bottle up the chagrin that she suffered from having lost authority over Wedano's house; but in the end she felt it unendurable to see, whenever she came there, that everything proceeded in good order. The slaves now performed their service with zeal and pleasure, where before they had done everything out of fear. They flew off, each doing his utmost, at a wink of their master's; even Kraspoekol, out of consideration for Wedano, was treated with the utmost attention.

She was of a mind therefore to carry out some plan, through her familiar the mandor-esse, whereby the propriety and good order in the house of her brother-in-law would beg in to break down.

She succeeded in this, when one day as she was dining with Wedano she asked for a glass of wine, and, in the passion of recounting a story and with her customary liveliness, leaned so heavily with her elbow on the salver on which the boy brought it that the wine dashed onto her clothes and the glass to the ground. Kraspoekol, forgetting that she had no say in the house now, made such a scene that the whole company was amazed; and ended up by assuring them that if he were her boy he would get a thrashing that he would feel for fourteen days. Wedano calmly tried to show here that the boy had done nothing wrong, and that he should certainly hold back from punishing a good slave for a matter of this sort; whereupon Miss Kraspoekol let fall the following:

"Yes, it doesn't surprise me, that you don't punish such things; since you let your boys go out at night...."

"Soft, my sister, this goes too far; if it is true, then you should have warned me out of friendship, and not reproach me in your anger; and if it is not true, then you do wrong to cause me anxiety... . But who is it, who goes out at night?"

"It's September,"3 she answered. . . September was called and after being questioned, admitted that, two nights before, he had been tempted by a slave girl from the neighborhood, who had told him in the morning that she had been approached for this purpose by the mandor-esse, who had promised her, in the name of Miss Kraspoekol, four Spanish dollars if she were able to persuade one of Wedano's boys to sleep out of the house, and could inform her of this in the morning.

10ss; though I am of the op inion that one in fact improves the remaining slaves by no less than one loses on the slave sold; so I hold to advising those concerned to put a thief, gambler, or liar out of the house, and rather set him to work in one of the work-places of the Company, to their profit. If they choose to forgive him the first time, however, let them pay attention to his attitude after he has received his punishment. If he feels shame before his master, or before his fellow slaves; if the shame affects him more than the pain, there is hope of reform. But if he laughs it off, or affects indifference, send him away without delay. Nothing good will come of him. On the contrary, every blow that one gives him is a step towards the scaffold.

3. The Batavian Dutch commonly gave their slaves nicknames referring to some aspect of their appearance or circumstances. September seems to have been a fairly common soubriquet: at least it also occurs in one of the Surapati Babads. (See Ann Kumar, Surapati, Man and Legend: A Study of Three Babad Traditions [Leiden, 1976], p. 338.)--Trans. 
The owner of this girl was by chance eating with Wedano that afternoon, and was requested to call her. She recounted everything just as the boy had said; so that Miss Kraspoekol, finding herself in the wrong, and refuted by the force of truth, was covered with the utmost shame.

Everyone was shocked by this ignominious act, and looked at Kraspoekol with indignation. Wedano resumed the conversation:

"It pains me," he said to his sister-in-law, "that you compel me to request you never to set foot in my house again, and, the sooner the better, to quit the wing in which you 7 ive; a perfidy of this sort deserves no better treatment. As far as the boy is concerned, it would give me great pleasure to forgive him his error; for, without your four Spanish dollars, he may possibly never have thought to go out at night: but I shall punish him, to stand by my word, and give an example to the other slaves." Hereupon Wedano ordered him to be thrashed, and there and then taken to a ship which was about to sail to Banda, with a request to the owner to sell him for his account.

The slaves, who had not failed to notice the fairmindedness of Wedano in the matter of the spilled glass of wine, saw equally in the punishment of September, that their master kept his word, and that they lived in a house of good order; so that, well off as they were, they did everything as it should be done.

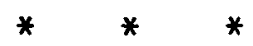

Kraspoeko1, who had now to leave her brother-in-law's compound, was at a loss; but the mandor-esse helped her out.

"You know," she said, "that the compound next to this is to let: move into it. How could you have a better opportunity to repay wedano for the insult which he has done to you? There you will be on your own ground. A single ditch and a low hedge separate the two gardens; so that nothing can occur in one that is not heard in the other. We shall have double pleasure in our punishments, carrying them out just at the times when the tender-hearted Wedano is at home."

This proposal pleased Miss Kraspoekol. She immediately sent the mandoresse to the owner of the compound, which was let to her that very evening.

This move was begun on the very next day. Three or four planks laid over the ditch to provide an easy way saved much time and difficulty. Wedano saw too late, that he should have made himself master of this compound; for now he had to expect all the unpleasantnesses of a bad neighbor.

To prevent this, he intimated betimes to his sister that if she would promise to abstain in the future from such tricks as she had perpetrated, she could stay in the wing of the house, and everything that had happened before should be forgotten: but Kraspoekol, too much taken with her design, and spurred on by the mandor-esse, rejected this suggestion, and let Wedano know, that she had no need of his garden, or his house, or his wings.

Within three days the move was completed, but, alas! there were too few slaves to have dally punishments, and at the same time to carry out the household tasks properly. Kraspoekol's desire to revenge herself on Wedano was so great, however, that she would not postpone the purchase of slaves until a good 
opportunity; but rode round to the Negociants and, from one and another, bought eight "pieces."4

Kraspoekol brought this pleasing news to the mandor-esse, and before evening they had all arrived in the compound. The next day, various dispositions were made to which the slaves must strictly conform; and Miss Kraspoekol distributed each girl* who had as yet no boy* to one of the newly bought slaves; on the condition that they, as well as the other female slaves, should be shut up at evening in a room of the house, and no girl, except with the knowledge of Miss Kraspoekol, might spend the night with her boy.

It was not long before the chastisements commenced. No chair was put down too hard, no glass, by mishap, broken, no message too slowly carried out, and no least error committed, without they were punished in the most cruel fashion, and always when Wedano was at home.

This went so far, that Wedano, who was accustomed to eat in his back parior, withdrew to the front parior to put himself at some distance; but as soon as Kraspoekol became aware of this, she would inquire first where Wedano was eating, and upon that depended also the place of the chastisement, behind or in front of the house.

The pitiful moans of the unfortunates, especially when he was dining with good friends, began to vex Wedano so much, that he notified his sister-in-law that, if she continued in this way, he would be compelled to inform the Court of the nuisance which it was causing him.

This warning could achieve nothing. The severe regime continued, and had a) ready gone on for more than three months; when an unexpected occurrence put an end to it.

On a certain evening, when Miss Kraspoekol had come home early, one of the slaves who had been bought recently requested that the girl whom Kraspoekol had herself allotted him, might spend the night with him; which on the advice of the mandor-esse she refused. The boy went away dejected. A moment afterwards, the same girl, knowing nothing of this refusal, came to make the same request. Miss Kraspoekol, fancying that it was part of a scheme, was so infuriated by the impudence of this girl, that she forthwith had her soundly thrashed by two slaves.

One can readily comprehend, how pleasant it was for the mandor-esse to have a young slave girl punished for a request which her own years and repulsive countenance made no longer possible for her. Moreover, she had her beaten in the most cruel way, so that her continuous and extraordinary screams nearly caused a neighborhood fight, and Wedano, who was having his evening meal, flew out of his chair, and called out to the mandor-esse over the ditch that he would inform the Fiscal 5 of this intolerable behavior in the morning.

* The words "boy" and "girl" used of slaves mean "man" and "woman."

4. I.e., elght slaves. The "piece" (stuk) is the numerator for slaves in Dutch documents of this period.--Trans.

5. One the earliest-established and most important criminal law officials under the Dutch East-India Company, the fiscal was charged with bringing to the notice of the Governor-General and Council any infringements of ordinances and regulations and any malpractice in the area of trade. He received a third share of fines and confiscations. (See Encyclopaedie van Ned. Oost-Indie 4: 127 ff.)--Trans. 
Humane Wedano! Trouble yourself not for the morrow; the vengeance of heaven, that so often makes use of human means, is swiftiy to rid you of a sister-in-1aw who fattens herself with the blood and tears of her slaves.

The boy who had gone away dejected, having now seen his girl chastised in this pitiless fashion, felt his sorrow change into a bitter hatred against Kraspoekol and the mandor-esse; and fretted the whole evening in the presence of the other slaves, at this cruel treatment.

It was the usual thing that, when Miss Kraspoekol was in bed, the boys, who were shut outside and had their sleeping places in the garden, got together to spend the night in games and gambling, or to go out and rob neighboring compounds,* for they got little betel-money, small portions of rice, and a very restricted selection of clothes.

All of them, as can be imagined, were vexed by a slavery which was so intolerable; but the smartest of them, having observed that this infuriated slave needed very little to reach the end of his tether, said to each other that they should do all they could, that night, to incite him, and to make the fires of anger burn ever more furiously in him.

While they were together he complained once again about the treatment his girl had received, and everyone agreed with him. They spoke of nothing except the heavy punishments that they had had to suffer for three months, and probabiy had still to expect in the future. Finally it was time for Opium; they endeavored to get him to take more than usual, which was not difficult; for anger had aiready intoxicated him.

The slaves who were with him saw well, that he was not far from running amok, by the muttering that he made between his teeth, and only half brought out.

It was time, however, that they all went to their sleep ing places; for Miss Kraspoekol and the mandor-esse sometimes got up before it was day, and woe to him who was found roaming about.

The enamoured slave, now in his sleeping place, felt even more deeply than before the sorrow of being separated from his girl, so that he became more and more furious, and finally, at break of day, resolved to revenge himself.

Miss Kraspoekol was accustomed, in the morning, to go with the mandor-esse to open the room where the girls were shut up, and afterwards, while drinking a cup of coffee in the parlor, to tell them what work they had to do; so that they could begin their tasks as soon as possible after washing and dressing.

The boy, descrying the moment when Kraspoekol and the mandor-esse came there, and being armed with a Kritze, flew out of his room, and fell on the seated and all unsuspecting Kraspoekol; and gave her a stab in the bosom that made her sink down from the chair, so that he thought that she was dead. Afterwards he fell at once upon the mandor-esse, whom he stabbed just the same way in the heart, so that she fell dead to the ground. The girls all fled to the front from fright and alarm. The boys watched this play from a distance; but acted as if they knew nothing about it.

"Now I am revenged and satisfied," said the boy, and ran off, as fast as he could, with the bloody Kritze in his hand, through the garden and over the

* This is the fate of all households where the slaves are badly paid, fed and clothed, and frequently beaten. They become gamblers and thieves. 
ditch, to the garden of Wedano, to throw himself at Wedano's feet, and inform him of the reason for the murder that he had committed.*

Wedano sat in his parlor, not yet dressed for the day, having nothing on but his Saron and Cabaai.6 His slaves, who never feared his presence, because of his goodness, were in, or close by the house. Campakka, seeing the amokrunner in the distance, threw herself on Wedano's lap, so that he could not be wounded except after she herself had been stabbed through. The slaves, who also saw the boy, made a half ring around their master; thus he sat, behind his people, as if behind a safe bulwark:** but one slave, who was by the side of the house, becoming aware of the amok-runner, ran after him, and gave him, when he was close to the parlor, a blow with an iron bolt that happened to be within his reach, between the neck and the shoulder of the amok-runner's right arm, so that the Kritze flew out of his hand, and he almost fell at Wedano's feet.

Wedano, very moved and alarmed, asked him:

"Wretch, what was your intention? Did you come here to murder me? What evil have I ever done you?"

"Oh! my Master," he answered, "far from wishing to murder you, I came here to throw myself at your feet, in order to confess my guilt to you, and surrender my 1 ife into your hands. Your sister. . . the mandor-esse . . . oh! I hardly dare to say it! both have treated me so severely for fully three months, and my innocent girl, whom they themselves gave to me and whom I now tenderly love, chastised so severely before my very eyes that I desired to revenge her and me; and in this I forthwith succeeded. I drove this Kritze into the hearts of both. My life was, in these circumstances, a burden to me. I know that I must now die; but that moment is no punishment to me. For I prefer to die, than to have to suffer daily pains worse than death. Oh! my Master, if only your sister-in-law had had your disposition, I should never have come to take such revenge, I should have served her with love and with pleasure!"

Campakka, who had the suspicion that Kraspoekol's slaves, under pretence of fear, would have rendered no help, and seeing that there was nothing more to fear for Wedano, slipped off, without him seeing her, to the house, where she found the mandor-esse lying dead on the ground; but perceived in Kraspoekol,

* One often sees that an amok-runner, after he has given vent to his revenge against the one who is its object, does no one else any harm, and throws himself at the feet of his master or of another.

** This is no mere story, as some who maintain that slaves are incapable of such fidelity and warm-heartedness towards their master might imagine. I was myself an eye-witness of something similar which happened to one of my good friends, in whose neighborhood there was a suspected amok; we all went out of the door, to see what was happening: it was dark; we heard someone coming, who was thought to be the amok-runner. Six or seven of the houseboys threw up a half-circle around their master to protect him. How long will European pride blind us to the innate good qualities of people who have been made slaves by trickery or force, and who are, by the laws of nature, as free as we are.

6. "Wedano zat in zyne gallery, ongekleed, hebbende niets dan zyne Saron en Cabaal aan." It was usual for European males to wear Indonesian dress at home, a state which Hogendorp describes as "undressed." He also does not distinguish too closely between different types of native dress, for a Kebaya ("Cabaai") is a woman's fitted top, whereas a man would probably have worn a sort of loose open jacket (baju).--Trans. 
though covered with her blood, still some signs of life. She immediately called some of the girls, who helped her to lay Kraspoekol on a couch, where she took her in her arms, and made a bandage for the wound out of the Cabaai, which was in shreds, to see if this could staunch the blood. In this she was more or less successful for a short time. Kraspoekol, who had come to herself somewhat through this movement, and possibly through the staunching of the blood, was conscious enough to recognize Campakka. She saw the tears run down her cheeks, and mingle with the shed blood! She was so strongly moved by this that she stammered out these words, though with a voice already faint:

"Oh! Campakka, is it you? You, whom I so short a time ago . . ! Alas! must I now . . . die in those arms... Which I had bound... ? sprinkled with those tears, that ... my cruelty could not wring from your eyes....? - shame.. . o heartache... I a heathen .. . so charitable . . I so humane .. . ! and I... a Christian ... ! so merciless. . . ! O Campakka - . I press me no longer ... in your arms. . . I am . . unworthy . . of this ald... ! My remorse... ! my repentance... ! my end approaches . . . ! Campakka . . . ! forgive me . . . my cruelty ... and let . . . my dying lips... bless you!"

As she was speaking these broken words, whether from the emotion, or from the strength which she had expended to bring them out, the blood spurted forth so strongly from the wound that Campakka could not staunch it, and, shortly after this, she gave up her soul.

Wedano, who had spent these moments at his house giving the necessary orders for the notification of the Law and the taking into custody of the amokrunner, went however as soon as he could to the house of his sister-in-law; but he found her already lying dead in Campakka's arms.

In the meantime the Law arrived; and since the slave was severely wounded, and had confessed everything, he was, as was customary, broken upon the cross in front of Kraspoekol's house that very morning.

He let himself be led with an undaunted courage to the cross:

"I know," he said, "that I have deserved death; but I have revenged myself, and that is enough; I die in peace." He was placed on the cross, and at every blow which the executioner gave him, he turned his eyes to the broken member without uttering a cry. He was left lying there until midday, when he was finally made an end of.

Thus ended this unhappy affair. Kraspoekol was buried that evening, and her name placed among those of those women who must blame themselves for the sad consequences of an excessive severity towards slaves. 


\section{APPENDIX: THE VAN HARENS AND THE INDIES IN DUTCH LITERATURE}

Like the van Hogendorps, the van Harens were an old aristocratic family and Onno Zwier van Haren was a confidant of Willem IV, who appointed him successively to a number of important positions in representative government and in diplomatic and military service. His services in the national and Orangist cause ensured him the powerful protection of the Stadhouder and his consort, but on Willem IV's death he became vulnerable to political rivals, notably the Hertog of Brunswijk-Wolfenbuttel, guardian of willem $V$ in his minority, for whom van Haren's advocacy of Dutch neutrality in European affairs was unacceptable. At this juncture, van Haren's daughter Carolina and her 16-year-old sister made a declaration to the effect that their father had attempted to have incestuous relations with them, a declaration made just as the banns were being called for Carolina and willem van Hogendorp.l After his father had suspended the banns, Willem van Hogendorp sent a messenger to tell van Haren that the marriage could only go ahead if he signed a confession and left the country. 2 Van Haren agreed to this, though he returned to the Netherlands and retracted $h$ is confession in the following year. His attempts to take up public office again were frustrated, though he was not without partisans. Whether the accusations which ended his public career were justified or should be seen as part of a callous political conspiracy is still a matter for debate.

At the age of fifty-three Onno Zwier began to write: his elder brother Willem had already embarked on a literary career and both brothers were admirers of French classicism, the school of Corneille, Racine, Crebillon, and Voltaire. The mother tongue of their circle was not Dutch but a slightly Dutch-ified French, and later critics have commented adversely upon the effect this had on their literary use of Dutch. 3 What is perhaps of more interest to students of Indonesia, however, is that they were among the first writers to portray events in the Indies--though neither of them ever went there--for a Dutch audience and to raise questions concerning the morality of Dutch actions there. Willem wrote both a poem in praise of Governor-General van Imhoff and a longer poem. Op den moord gepleegd aan de Chineezen te Batavia den 9 October anno 1740 [On the massacre perpetrated on the Chinese of Batavia the 9th of October 1740], describing the bloody massacre of all Chinese remaining in Batavia after large numbers had fled to the countryside to organize armed resistance. 4 In this poem the author calls for the punishment of those guilty of the massacre for the sake of Holland's good name.

Onno Zwier's first tragedy, which appeared in 1769, was entitled Agon Sultan van Bantham, and based on the 1 ife of Sultan Agung (Ageng) of Banten ( $r$. 16511682), though the events of several years are presented as taking place in a single day. This was the first play to put a Javanese subject on the Dutch

1. The calling and interruption of the banns is recorded in the geslacht en wapenkunde (family and genealogy) section of the Navorscher (1904): 49.

2. On Willem van Haren, see NNBW 6:689-93, and Nieuwenhuys, Spiegel, pp. 61-65.

3. See e.g., Meijer, Literature, p. 166. (Voltaire was not so critical: he wrote a poem in praise of Willem van Haren's Leonidas, calling its author "Pindare au Parnasse.")

4. On the events of 1740--the beginning of the "Chinese War"--and the general warfare which subsequently developed on Java, see M. C. Ricklefs, A History of Modern Indonesia (London: Macmil1an, 1981), p. 87. 
stage, and different explanations have been given of the reasons behind the author's choice of subject. Meijer writes that the play is written entirely from the point of view of the Javanese, and that van Haren was "undoubtedly moved by the fate of the Javanese prince who lost the independence of his country under such tragic circumstances, but, undoubtediy also, he used the play as a vehicle for the anger he felt towards the Dutch for what had happened in his personal 1ife."5 The analogy with van Haren's political downfall is obvious enough, as Ageng, a determined opponent of the trade monopoly of the voC, was eventually dethroned through the Company's use of his rebellious son Sultan Aji. Nieuwenhuys, however, says that van Haren had considered four possible subjects and chose Ageng only because the other three did not conform to the technical requirements of the eighteenth-century tragic verse drama, and that the choice of an "oriental" subject was an established fashion. 6 He nevertheless goes on to say that the writing of the play--the "technical" necessity for the author to identify with the hero's position--seems to have brought about an intellectual and emotional identification of van Haren and Ageng's position.

Two points can be raised here: one concerning the choice of subject, the other the tone in which the play sets it forth. It could be argued, I think, that the act of choice itself--the choice of one of the Company's, by extension the nation's, foremost enemies as the tragic hero--was in itself a radical act for the times, however much this subject conformed to the technical requirements of the genre. Secondly, a reading of the play reveals that it is not a tragedy which hinges upon the play of circumstance and mischance, nor one which hinges upon the fatal $f 1$ aw in individual character (in traditional terminology, hamar$t i a)$ : it is a tragedy where the heroic party are doomed by the actions of enemies who refuse to pursue their interests with in the accepted rules of civilization and morality. The Bantenese depict the Dutch as robbers, inhuman murderers without shame or honor; avaricious; free in Holland, but enemies to any Eastern freedom; their mercantile spirit already counting the profits of Banten's slavery.7 In the diagnosis of the Indies' weakness put into Agung's mouth, an opposition between the existing Disunity (Tweedracht) and the sought-for Unity (Eendracht) echoes through the play. Though one cannot dispute that van Haren did not have Multatuli's understanding of Javanese realities, one must acknow 1edge that both his critique of the moral basis of Dutch power and his diagnosis of the need for the Indies to move from disunity into unity were to be the main thrust of nationalist analyses nearly one and a half centuries later.

None of the succession of tragic and lyric works which willem van Haren wrote after Agon is set in the East Indies. These later works are strongly patriotic, religious, and Orangist in tone and also include a poem in praise of trade, as exemplified in the aristocracies of Venice and Florence, as an instrument of social and moral betterment.

5. Meijer, Literature, p. 169.

6. Nieuwenhuys, Spiegel, pp. 62-63. Nieuwenhuys is presumably referring to the prominence of exotic locales in the works of French dramatists such as Racine and Voltaire. Van Haren had previously written a biography of Governor-General Camphuis (1634-1695), which introduced him to the events of Agung's reign.

7. See Onno Zwier van Haren, Agon, Sulthan van Bantam, Treurspel in vijf bedrijven, ingeleid en geannoteerd door G. C. de Waard (Zwolle: Tjeenk W111ink, 1968), Pp. 73, 92, 97-98. In this critique (unanswered in the play itself) of the moral basis of Dutch power, rather than of abuses perpetrated by flawed individuals, Agon is, in my reading, more radical than Kraspoekol. 